\title{
THE PROBLEM OF LIBERALIZING ISLAMIC MARRIAGE LAW IN INDONESIA : The Perspective Of Science Philosophy
}

\author{
Oleh. Athoillah Islamy \\ Institut Agama Islam Negeri (IAIN) Pekalongan, Indonesia \\ athoillahislamy@yahoo.co.id
}

Article history:

Received: 01-06-2020 Revised: $15-06-2020 \quad$ Accepted: 20-06-2020

\begin{abstract}
The phenomenon of liberalism on Islamic marriage law in Indonesia often creates social problems. Therefore, it is important to understand understanding and wise attitudes towards the phenomenon within the framework of the scientific paradigm. This research aims to understand various forms of liberalism on Islamic marriage law in Indonesia in the perspective of the philosophy of Science. This research is a qualitative research in the form of literature review. The type of legal research in this study is philosophical normative legal research. The research data used is various research on liberalism on the law of Islamic marriage in the Compilation of Islamic Law (KHI). Meanwhile, the theory used as a knife of analysis is the theory of the scientific revolution of Thomas Samuel Kuhn.

This study concludes that liberalism on Islamic marriage law in Indonesia is a form of paradigm shift over the construction of legal thinking in various KHI articles that are considered to have experienced anomalies, which are not relevant to social development and do not answer the challenges of modernity, such as issues of gender equality, democracy, human rights Humans, and pluralism. Such conditions have encouraged contemporary Islamic law reviewers in Indonesia to voice a paradigm shift and even a scientific revolution by giving birth to the construction of new Islamic marriage law.
\end{abstract}

Keyword: Islamic Marriage Law; Indonesia; Liberalism; Philosophy of Science.

\begin{abstract}
Abstrak
Fenomena liberalisme terhadap hukum perkawinan Islam di Indonesia sering menibulkan problem sosial. Oleh sebab itu, penting upaya pemahaman maupun sikap yang bijak terhadap fenomena tersebut dalam kerangka paradigma ilmiah. Penelitian ini bertujuan untuk memahami berbagai bentuk liberalisme terhadap hukum perkawinan Islam di Indonesia dalam perspektif filsafat Ilmu. Penelitian ini merupakan penelitian kualitatif yang berupa kajian pustaka. Jenis penelitian hukum dalam penelitian ini, yakni penelitian hukum normatif filosofis. Data penelitian yang digunakan, yakni berbagai riset tentang liberalisme terhadap huku perkawinan Islam dalam Kompilasi Hukum Islam (KHI). Sementara itu, teori yang digunakan sebagai pisau analisis, yakni teori revolusi ilmiah Thomas Samuel Kuhn.
\end{abstract}


Penelitian ini menyimpulkan bahwa liberalisme terhadap hukum perkawinan Islam di Indonesia merupakan bentuk pergeseran paradigma atas kontruksi pemikiran hukum dalam berbagai pasal KHI yang dianggap sudah mengalami anomali, yakni tidak relevan dengan perkebangan sosial dan tidak menjawab tantangan modernitas, seperti isu kesetaraan jender, demokrasi, Hak Asasi Manusia, dan pluralisme. Kondisi demikian telah mendorong para pengkaji hukum Islam kontemporer di Indonesia menyuarakan pergeseran paradigma bahkan revolusi ilmiah dengan melahirkan kontruksi hukum perkawinan Islam baru.

\section{Kata kunci: Hukum Perkawinan Islam; Indonesia; Liberalisme; Filsafat Ilmu.}

\section{A. Introduction}

As a product of modernization and positification of Islamic family law, ${ }^{1}$ the existence of the Compilation of Islamic Law (KHI) in the course of its history is not free from polemics. ${ }^{2}$ Among the existing polemics is post-reformation, the liberalism movement of Islamic legal thinking is increasingly enlivened by reviewers of Islamic law with various multidisciplinary approaches. It is not uncommon to produce renewal products of Islamic legal thinking that are different from the mainstream Islamic legal paradigm. Therefore, the liberalism of Islamic legal thought often causes controversy and polemics in society. So how exactly is the liberalism of Islamic marriage law thinking in Indonesia in the paradigm of the philosophy of science?

There are several previous studies that are relevant to this research. Sadari explained that realizing a modern and civil Islamic family law required the renewal of the construction of various KHI articles. These reforms can be done by reviewing the construction of various KHI articles in the perspective of human rights, democracy, nationalism and constitutionalism in Indonesia. ${ }^{3}$ Then Asni in her dissertation stated that there are some in KHI that gender bias is not in line with the spirit of gender relations patterns in Indonesia. Asni stressed the need for a review of some of the gender biased articles while still referring to the shariah

\footnotetext{
${ }^{1}$ Tahir Mahmud, Family Law Reform In The Muslim World (Bombay : NM. Tripathi PVT LTD, 1972), h. 3-8.

2 Nasrullah Ali Munif, "KHI Dan Konfigurasi Politik Hukum Orde Baru (Vis a Vis Antara Hukum Islam dan Sistem Pemerintahan Otoriter)," Abkam, Vol.3, No.2 (2015), h. 285.

${ }^{3}$ Sadari, "Studi Islam dalam Kajian Hukum Keluarga Islam di Indonesia," Indonesian Journal of Islamic Literature and Muslim Society,Vol.1,No1(2016): h. 82-83.
} 
maqasid and the spirit of gender relations in Indonesia. ${ }^{4}$ Abul Khoir in his research looked more at the paradigmatic foundation of the Islamic legal liberalism movement towards the existence of KHI. Abul argues that the liberalism movement of Islamic legal thinking towards the Compilation of Islamic Law as practiced by the Counter Legal Draft Team of KHI is more based on the liberal paradigm. This is different from the paradigm of KHI which is based more on usul fiqh and classical fiqh opinions. ${ }^{5}$ Meanwhile, Athoillah Islamy in his research concluded that the liberalism of Islamic marriage law in Indonesia after the reformation era was an open discourse due to the wide open door of democracy, but did not significantly influence the existence of KHI. ${ }^{6}$

In contrast to the above research, in this study the author will explain how the existence of liberalism in Islamic marriage law thinking in the perspective of the philosophy of science. Through mapping the scientific revolution theory of Thomas Samuel Kuhn, this research is expected to be able to answer the validity of liberalism of Islamic marriage law thinking in Indonesia, namely whether liberalism can be accounted for in the perspective of the philosophy of science or not.

\section{B. Discussion And Result}

\section{Paradigm Shift And Scientific Revolution}

Thomas Samuel Kuhn argued, the existence of a science that has become a paradigm will be able to experience a crisis, then a science revolution will emerge. Then science experiences a development that is always happening even significant. In the revolution that can deliver a new normal science. And so on until a dynamic scientific development is formed. ${ }^{7}$ Kuhn added that the concept of a paradigm shift had opened up a shared awareness that not always believing the truth of a scientific

4 Asni, Pembaharuan Hukum Islam Di Indonesia: Telaab Epistemologis Kedudukan Perempuan Dalam Hukum Keluarga (Jakarta :Kementrian Agama Republik Indonesia, 2012), h. 287-288.

5 Abul Khair, "Telaah Kritis Counter Legal Draft KHI (Reorientasi Hukum Keluarga Islam Indonesia)," al-Risalah, Vol.2, No.1 (2016), h. 35-36.

6 Athoillah Islamy, "Eksistensi Hukum Keluarga Islam di Indonesia dalam Kontestasi Politik dan Liberalisme Pemikiran Islam," Al-Istinbat : Jurnal Hukum Islam, Vol. 4, No.2(2019), h. 173-174.

${ }^{7}$ Mu'ammar Zayn Qadafy, “Revolusi Ilmiah Thomas Samuel Kuhn (1922-1996) dan Relevansinya Bagi Kajian Keislaman,” Al Murabbi, Vol.1 No. 1(2014), h. 49-50. 
product was final. In other words, objectivity or scientific truth is relative and there are times when validity is doubted so that it moves to the new paradigm. Therefore, in these conditions, scientists should always carry out scientific research with a variety of new scientific approaches and innovations, so that they can find the normal set of knowledge (normal science) and no longer doubt its truth. At this normal stage of science, science is able to answer problems and be able to come up with solutions. But over the times, the existence of science will be able to experience the inability and even failure to answer the problems that arise which under these conditions an anomaly is born.

The condition of the anomaly can have implications for doubts for the community over the truth of an existing scientific paradigm that encourages them (the public) to find a new paradigm that can offer solutions. Not only stop at the new paradigm, other scientists will also conduct further research to examine the truth of the new paradigm. So if the new paradigm can be accepted as a scientific truth and defeat the old paradigm, then the old paradigm will begin to be abandoned and move on to the new paradigm. This condition was later called by Kuhn as a paradigm shift (paradigm shifting). ${ }^{8}$

After a paradigm shift in a science, Khun introduced the term scientific revolution, which is a condition of significant change in the progress and development of science from the old paradigm by being replaced in whole or in part by a new paradigm which can be said to be contradictory. Therefore, in these conditions can cause fundamental differences or changes between the old paradigm with the new paradigm. Where it shows that the development and progress of a scientific theory is revolutionary, fast and drastic. Khun added that the paradigm shift can occur when scientists face anomalies that cannot be answered by the old paradigm. $^{9}$

\footnotetext{
${ }^{8}$ Thomas Kuhn, The Structure Scientific of Revolutions (Chicago: The University of Chicago Press, 1970), Second Edition, h. 144-160

9 Turkan Firinci Orman, "Paradigm as a Central Concept in Thomas Kuhn's Thought," International Journal of Humanities and Social Science, Vol. 6, No.10(2016), h. 50 .
} 
Kuhn divides the process of the formation of a science into three phases. The first phase, when the existence of the status of a knowledge is still in prescience. In these conditions the form of knowledge is still being debated continuously by many people. In this phase, the number of theories is as much as the number of observations or experiments carried out by many people. Therefore, there is no agreement on certain theoretical assumptions. In this phase, thinkers are often divided into various small groups that compete with one another in gaining legitimacy for each theory of knowledge until it becomes a scientific discipline.

The second phase, after becoming an ordinary science (normal science), then a knowledge has been recognized and mastered by a paradigm that is always open to all new possibilities and adjustments. The third phase is the paradigm shift. Those three stages are according to Kuhn who became the ideal circulation of knowledge. But Kuhn regretted that the circulation was often problematic, namely stopping at normal science, so what happened was a single paradigm that dominated the scientific theory community. ${ }^{10}$ Kuhn's opinion can thus be concluded that the truth in a scientific theory is relative.

The paradigm in a theory of science will guide scientists in answering problems with an existing meetode. But when the paradigm fails to answer, then the failure can eventually reach the level of seriousness which is a serious crisis for the initiators and can also cause rejection of an existing paradigm. Kuhn realized that the journey of the paradigm would face difficulties, namely passing the anomalous phase. ${ }^{11}$ Therefore, the development of a dynamic era, the old paradigm (the first paradigm) that has been established as happened at the normal stage of science allows analytic paralysis or unable to provide answers and explanations to various problems that arise. At this stage, it is called the anomalous phase, which is the phase where scientists are no longer able to avoid conflict because there are many deviations. As a result that arises because of the many anomalies, the crisis arises. It was during this crisis phase that the first paradigm began to doubt its truth,

\footnotetext{
${ }^{10}$ Mu'ammar Zayn Qadafy, "Revolusi Ilmiah Thomas Samuel Kuhn (1922-1996) dan Relevansinya Bagi Kajian Keislaman,", h. 50-51.

${ }^{11}$ A.E Chalmers, What is this thing called Science? (Queensland : University of Queensland Pres,1999), h. 112-113.
} 
which could then lead to a revolutionary phase. In this phase of the revolution then a new paradigm (the second paradigm) emerges as the answer to the problems that arise from the previous (first) paradigm. These changes indicate that there will be no change in paradigm without being preceded by crisis conditions. Nevertheless the role of the old paradigm is still considered as an important thing that leads a scientist to the anomalous condition which is a prerequisite for the discovery of new knowledge to fill the gap of emptiness or ignorance. ${ }^{12}$

\section{Typology of Liberalism Thought of Islamic law}

According to Greg Barton as quoted by Abdullah, he explained that there were four Islamic liberalization programs in Indonesia, among others ijtihad's contextualization, rationalization and renewal, social pluralism and religious pluralism, and the separation of religion from political affairs. From these various programs also gave birth to four major objects of the Islamic thought liberalism movement in Indonesia, namely the liberalization of the creed, the liberalization of the interpretation of the Qur'an, the liberalization of Islamic law, and the liberalization of studies in Islamic Higher Education. ${ }^{13}$ Liberalism in Islamic legal thinking in general is inseparable from the following four issues. ${ }^{14}$

First, the issue of democracy. There are a variety of responses to the term democracy, both in the area of concept and political systems of government in Islamic countries. There are at least three schools of Islamic thought related to democracy. The first stream, which is a stream that holds that Islam and democracy cannot be combined. The second stream, which is a stream that accepts the principles of democracy, but still recognizes differences. The difference in question, namely the difference in the paradigm of democracy from the west which gives enjoy absolute sovereignty of the people. Whereas Islamic democracy is limited by the limits of religious law. The third stream, namely the flow of Islamic

\footnotetext{
${ }^{12}$ Thomas Kuhn, The Structure Scientific of Revolutions, 43-77.

${ }^{13}$ Abdullah, Respom Masyarakat Muslim Terhadap Liberalisasi di Indonesia," Sulesana, Vol.10, No.2(2016) : h. 75-78.

${ }^{14}$ Muhammad Taufik "Pandangan Kritis Islam Liberal atas Isu-isu Kontemporer," Al-Banjari, Vol. 14, No. 1(2015) : h. 91-97.
} 
thought that fully accepts the concept of democracy by correlating with the values of Islamic teachings which are also very democratic.

Second, Human Rights (HAM). In this case, there is a view that states the dialectics of human rights principles in Islamic teachings. The teachings referred to, namely the five main objectives of Islamic law for the benefit of humans, among others, hifz al-din (protection of religion), hifz al-mal (protection of property), hifzu al-nafs (protection of the soul), hifz al-'aql (protection of reason) and hifz al-nasab (protection of descent).

Third, Pluralism. The awareness of the importance of the pluralistic spirit in the plurality of a society or nation must be to realize the upholding of justice and security of human life together.

Fourth, gender. The awareness and understanding of the factors that cause women to be discriminated against is not only caused by a gender biased social system, but also by a gender biased interpretation of the normative basis of Islamic theologians (al-Qur'an and Hadith). It is this awareness that then drives the reinterpretation of existing Islamic legal doctrines or products. ${ }^{15}$

\section{Liberalism Legal Thought of Islamic Marriage in Indonesia: Perspectives of the Scientific Revolution}

The liberalism movement of Islamic marriage law in Indonesia has been carried out by many reviewers of Islamic law, both collectively and individually. After the reform era, the existence of KHI has experienced criticism from a group called the Counter Legal Draft (CLD) -KHI team. A group acting as a team to formulate pluralist, democratic, humanist and gender-just Islamic law as a form of counter (counter) to the draft formulation of KHI. The CLD-KHI team also offered the building of Islamic legal products that accommodate the conditions of the Indonesian people with all the characteristics of nationality, culture and progress in democracy and upholding Human Rights (HAM). There are three arguments from the CLD-KHI team in counter-formulating the legal articles in KHI. First, KHI has a weakness in its vision and mission in various article formulations in it. There are

15 Athoillah Islamy, Diskursus Hak Perempuan Sebagai Wali dan Penghulu Nikah Di Indonesia (Ciputat : Cinta Buku Media, 2016),h. 25-26. 
several articles which are counterproductive to universal Islamic values such as: equality, brotherhood and justice. Secondly, there are several KHI articles that are not relevant to the applicable laws and regulations and ratified International conventions. Third, from a methodological point of view, KHI seems to be a replica of the classical Jurisprudence law of Arab society. The construction of the KHI law article formulation has not been conceptualized in the viewpoint of the Indonesian Islamic community. ${ }^{16}$

Not only conducted by the CLD-KHI team, the liberalism of Islamic marriage law in Indonesia is also done through individual research. In his research, Wardah Nuroniyah stated that the KHI methodology framework had not been carried out consistently in all its articles. According to Wardah, the renewal of KHI is only in a number of articles. While some other articles are still ignored, so it is still as in classical Jurisprudence. ${ }^{17}$ Then Asni in her dissertation argued that the articles in KHI that were identified as gender biased needed to be reviewed by still referring to the shariah maqasid and the spirit of gender relations in Indonesia. ${ }^{18}$ Realizing in his dissertation also stated that by conducting a hududi study (boundary theory) offered by Syahrur on the formulation of KHI law, it would give birth to progressive KHI products in accordance with the spirit of modernity and Indonesia. $^{19}$

Not only that, Sadari also further explained that the relevance and modernity of the existence of the Compilation of Islamic Law (KHI) would be said to be civil if it could carry out two-way processes that are interrelated in the context of nationality and state, among others. First, compiling coherent KHI with human rights and coherent human rights with KHI. Second, compile coherent KHI with

16 Marzuki Wahid, Fiqh Indonesia, h. 232.

17 Wardah Nuroniyah "Pembaharuan Hukum Perkawinan DI Indonesia (Studi Terhadap Kontruksi Ushul Fikih Dalam KHI)," (Disertasi, Sekolah pascasarjana UIN Syarif Hidayatullah Jakarta, 2016), h. 229-230.

18 Asni, Pembaharuan Hukum Islam Di Indonesia: Telaah Epistemologis Kedudukan Perempuan Dalam Hukum Keluarga (Jakarta : Kementrian Agama Republik Indonesia, 2012), h. 287-288.

19 Sadari, "Sakralisasi Vis-a-Vis Desakralisasi Hukum Keluarga Islam Di Indonesia (Studi Hududi untuk Relevansi Modernitas dan Keindonesiaan)." (Disertasi Sekolah Pascasarjana UIN Syarif Hidayatullah Jakarta, 2014) : h. 262-263 
democracy and democratize coherent democracy with KHI. Third, compile coherent KHI with nation state and nationalize coherent nation state with KHI. Fourth, compile coherent KHI with civil society and civil society coherent coherent with KHI. Fifth, compile coherent KHI with constitutionalism and constitute coherent constitutionalism with $\mathrm{KHI} .{ }^{20}$ Actually there are many other research results of other academics who try to criticize the construction of KHI law while offering ideas for KHI renewal. But in this case, the author does not explain everything in this paper.

Various arguments underlying the legalism of marriage law in KHI, both those initiated by the CLD-KHI team and individual research can be said as a form of awareness of anomalies that occur in the construction of various KHI article formulations. The anomaly meant is that the formulation of the existing article is no longer relevant to the social development of Indonesian society. As what was said by Kuhn, that dynamic social development, can make the old paradigm that has been established can not provide answers and explanations for various problems that arise. This condition was later called by Kuhn as a paradigm shift (paradigm shifting) ${ }^{21}$ Therefore, Islamic marriage legal liberalism is a form of updating the old legal paradigm to the new legal paradigm.

As explained earlier, there are at least three basic arguments for the liberalism of Islamic marriage law thinking, both from the CLD-KHI team and the individual research of the figures. First, some articles of marriage law in KHI are counterproductive to universal Islamic values such as equality, brotherhood and justice. Second, some articles of marriage in KHI are not relevant to the applicable laws and regulations and international conventions that have been ratified. Third, the methodology for the formulation of marriage law in KHI is a replica of the classical Jurisprudence law of the Arab community that has not been conceptualized in the perspective of the Indonesian Islamic community. ${ }^{22}$

\footnotetext{
${ }^{20}$ Sadari, "Studi Islam dalam Kajian Hukum Keluarga Islam di Indonesia," Indonesian Journal of Islamic Literature and Muslim Society,Vol.1,No1(2016): h. 82-83.

${ }^{21}$ Thomas Kuhn, The Structure Scientific of Revolutions, h. 144-160

22 Marzuki Wahid, Fiqh Indonesia, h. 232.
} 
In the terminology of Kuhn's scientific revolution, the three basic arguments for the liberalism of marriage law above can be called an anomaly in the construction of the law leading to a crisis. It was during this crisis phase that the legal construction paradigm in KHI began to doubt its truth, which could then lead to a revolution in the construction of new laws.. ${ }^{23}$ From this it can be concluded that actually in the paradigm of the philosophy of science, Islamic marriage legal liberalism in Indonesia is a form of paradigm shift and scientific revolution caused by various anomalies that occur in the construction of marriage law in KHI. This is actually a form of development or legal reform that can be scientifically justified and justified. Although on a practical level in society receives massive resistance.

\section{Conclussion}

Based on the discussion in this paper, it can be concluded that the various movements of Islamic marriage legal liberalism in Indonesia, both collectively and individually, are a form of awareness of the importance of a paradigm shift and a scientific revolution over the construction of the law contained in KHI. That is caused by various anomalies in the existing legal construction, namely the construction of marriage law in KHI is no longer relevant to social change and is not responsive to the problems of modern society, such as issues of gender equality, democracy, human rights, and pluralism. Therefore, in the paradigm of the philosophy of science, it is actually a form of development or legal reform that can be scientifically justified and justified.

\section{BIBLIOGRAPHY}

Abdullah, "Respom Masyarakat Muslim Terhadap Liberalisasi di Indonesia,”Sulesana, Vol.10, No.2 (2016).

Asni, Pembaharuan Hukum Islam Di Indonesia: Telaah Epistemologis Kedudukan Perempuan Dalam Hukum Keluarga (Jakarta :Kementrian Agama Republik Indonesia, 2012).Sebuah disertasi UIN Alaudin Maksar 2012 yang telah dibukukan.

\footnotetext{
${ }^{23}$ Thomas Kuhn, The Structure Scientific of Revolutions, h. 43-77.
} 
Firinci, Turkan Orman, "Paradigm as a Central Concept in Thomas Kuhn's Thought," International Journal of Humanities and Social Science, Vol. 6, No.10, 2016.

E Chalmers, A, What is this thing called Science?, Queensland : University of Queensland Pres, 1999.

Islamy, Athoillah. "Eksistensi Hukum Keluarga Islam di Indonesia dalam Kontestasi Politik dan Liberalisme Pemikiran Islam," Al-Istinbat : Jurnal Hukum Islam, Vol. 4, No.2, 2019.

-------, Diskursus Hak Perempuan Sebagai Wali dan Penghulu Nikah Di Indonesia, Ciputat : Cinta Buku Media, 2016.

Irawan, "Al-Tawassut wa al-I'tidal: Menjawab Tantangan Liberalisme dan Konservatisme Islam," Afakruna, Vol.14, No.1, 2018.

Kuhn, Thomas, The Structure Scientific of Revolutions, Chicago: The University of Chicago Press, 1970).

Khair, Abul "Telaah Kritis Counter Legal Draft KHI (Reorientasi Hukum Keluarga Islam Indonesia)," al-Risalah, Vol.2, No.1. 2016.

Mahmud, Tahir, Family Law Reform In The Muslim World, Bombay : NM. Tripathi PVT LTD, 1972.

Nuroniyah, Wardah "Pembaharuan Hukum Perkawinan DI Indonesia (Studi Terhadap Kontruksi Ushul Fikih Dalam KHI)," Disertasi, Sekolah pascasarjana UIN Syarif Hidayatullah Jakarta, 2016.

Sadari, "Sakralisasi Vis-a-Vis Desakralisasi Hukum Keluarga Islam Di Indonesia (Studi Hududi untuk Relevansi Modernitas dan Keindonesiaan).” Disertasi Sekolah Pascasarjana UIN Syarif Hidayatullah Jakarta, 2014.

-------, "Studi Islam dalam Kajian Hukum Keluarga Islam di Indonesia," Indonesian Journal of Islamic Literature and Muslim Society, Vol.1,No1, 2016.

Taufik, Muhammad, "Pandangan Kritis Islam Liberal atas Isu-isu Kontemporer," Al-Banjari, Vol. 14, No. 1. 2015.

Wahid, Marzuki, Fiqh Indonesia : Kompilasi Hukum Islam dan Counter Legal Draft Kompilasi Hukum Islam Dalam Bingkai Politik Hukum Indonesia, Cirebon : ISIF, 2004M.

Zayn, Mu'ammar Qadafy, "Revolusi Ilmiah Thomas Samuel Kuhn (1922-1996) dan Relevansinya Bagi Kajian Keislaman,” Al Murabbi, Vol.1 No. 1. 2014.. 